\title{
Effects of roads and adjacent areas on diversity of terrestrial isopods of Hungarian highway verges
}

\author{
Diána VonA-Túri ${ }^{1}$, Tünde SzmatonA-Túri ${ }^{2} \&$ Balázs KISS $^{3}$ \\ ${ }^{1}$ Eötvös József Reformed Education Center, 29 Dobó Street, Heves 3360, Hungary; e-mail: turidiana79@gmail.com \\ ${ }^{2}$ FM ASzK - Forestry, Agricultural and Game Management Training School and Student Hostel of Mátra, 11 Erdész street, \\ Mátrafüred 3232, Hungary; e-mail: turitunde79@gmail.com \\ ${ }^{3}$ Center of Agricultural Research, Hungarian Academy of Sciences. Plain Protection Institute, 15 Herman Ottó Road, \\ Budapest, 1022 Hungary; e-mail: kiss.balazs@agrar.mta.hu
}

\begin{abstract}
Transportation infrastructure may be the most important driver of social and economic development, but it is a major cause of environmental change in landscapes. The main objective of this paper is to report road edge effects on isopods of Hungarian highway verges. We examined the isopod diversity along five highways (M0, M1, M3, M5, M7) while accounting for road edge proximity and the adjacent areas. Double-glass pitfall traps were set in a total of 15 sites and at three distances from the edge of the roads next to different types of adjacent areas. We found differences between ecological parameters of isopod communities in relation to adjacent areas as well as to road edge proximity. The highest diversity was observed near urban areas, while the lowest was near the arable fields. Isopod diversity increased with decreasing distance from a road. Species diversity of different types of verges based on adjacent areas varied strongly in relation to road edge proximity. A medium distance $(40 \mathrm{~m})$ from roads had a positive effect on species richness, while verges next to arable fields were the most species-rich habitats. The general conclusion of this study is that highway verges provided suitable environment conditions for generalist isopod species but may be a limiting factor for specialist isopods. Moreover, highway verges function as corridors for isopods. The proximity of roads and urban areas positively affected isopods, and verges close to roads and urban areas are considered as an attractive environment for isopods in heterogeneous roadside verges.
\end{abstract}

Key words: linear infrastructure; species richness; road edge proximity; vegetation structure

\section{Introduction}

Terrestrial isopods are widely distributed and are easily identified soil-dwelling macrodecomposers. In the temperate regions, they represent dominant saprophagous members of the soil macrofauna (Hassall et al. 1987; Paoletti \& Hassall 1999). Isopods can adapt well to modified habitats and have successfully colonised the majority of continental areas (Schmidt 2008). Terrestrial isopods are potential bio-indicators of environmental quality in polluted, disturbed and natural habitats (Dallinger et al. 1992; Paoletti \& Hassall 1999). The temperature and the humidity of the environment is a limiting factor for them and they are confined to microhabitats where suitable conditions such as food sources, detritus, and the temporal continuity of the area are available (Spencer \& Edney 1954). Despite this, they also widely tolerate dry habitats (Smigel \& Gibbs 2008).

Large-scale transportation infrastructure such as highways contribute to the creation of roadside ditches, grassland corridors and roadside verges, where endangered, native, exotic and invasive species can adapt successfully (Ries et al. 2001; Tikka et al. 2001; Brisson et al. 2010; Holderegger \& Di Giulio 2010; Noordijk et al. 2011; Vona-Túri et al. 2013, 2015, 2016). In modified habitats, invasive species have a chance to adapt and spread along roadsides (Alaruikka et al. 2002), but invaders alter community structure through resource use and other species interactions that lead to a reduction in the distribution of other native species and, ultimately, species extinctions (Charles \& Dukes 2007). Highway verges may function as connecting ecological corridors among natural habitats for several arthropod species (Hawbaker et al. 2006). Verges can be refuges for species which are sensitive to extensive disturbances caused by agricultural management (Ries et al. 2001; Purtauf et al. 2005; Noordijk et al. 2008). Beside the positive effects of roads on organisms, their negative effects are known, such as habitat destruction, altering the physical environment, road mortality, shifting animal behaviour, chemical pollution, acting as physical barriers and increasing the dispersal of invasive species (Trombulak \& Frissell 2000; Forman et al. 2002; Knapp et al. 2013). Roads do not have the same effect on all organisms. Higher trophic levels such as predatory arthropods are more sensitive to fragmentation (Bolger et al. 2000), while roads in- 
Table 1. Characteristics of the sampling sites.

\begin{tabular}{|c|c|c|c|c|}
\hline \multicolumn{2}{|c|}{ Types of adjacent areas } & \multirow{2}{*}{$\begin{array}{c}\text { Highway } \\
\text { M5 } \\
\text { M0 } \\
\text { M7 }\end{array}$} & \multirow{2}{*}{$\begin{array}{l}\text { Sampling site } \\
\text { Röszke } \\
\text { Ferihegy } \\
\text { Táska }\end{array}$} & \multirow{2}{*}{$\begin{array}{c}\text { Distance from the road }(\sim) \\
20 \mathrm{~m} \\
40 \mathrm{~m} \\
90 \mathrm{~m}\end{array}$} \\
\hline Natural and semi-natural & Grasslands & & & \\
\hline & Forest & $\begin{array}{l}\text { M5 } \\
\text { M3 } \\
\text { M1 }\end{array}$ & $\begin{array}{l}\text { Örkény } \\
\text { Kisbag } \\
\text { Óbarok }\end{array}$ & $\begin{array}{l}20 \mathrm{~m} \\
40 \mathrm{~m} \\
90 \mathrm{~m}\end{array}$ \\
\hline \multirow[t]{3}{*}{ Disturbed } & Urban & $\begin{array}{l}\text { M0 } \\
\text { M7 } \\
\text { M0 }\end{array}$ & $\begin{array}{l}0 \mathrm{~km} \\
\text { Budaörs } \\
\text { Csepel }\end{array}$ & $\begin{array}{l}20 \mathrm{~m} \\
40 \mathrm{~m} \\
90 \mathrm{~m}\end{array}$ \\
\hline & Orchard & $\begin{array}{l}\text { M3 } \\
\text { M1 } \\
\text { M7 }\end{array}$ & $\begin{array}{l}\text { Ecséd } \\
\text { Turul } \\
\text { Velence }\end{array}$ & $\begin{array}{l}20 \mathrm{~m} \\
40 \mathrm{~m} \\
90 \mathrm{~m}\end{array}$ \\
\hline & Arable & $\begin{array}{l}\text { M7 } \\
\text { M3 } \\
\text { M5 }\end{array}$ & $\begin{array}{l}\text { Szegerdő } \\
\text { Polgár } \\
\text { Kecskemét }\end{array}$ & $\begin{array}{l}20 \mathrm{~m} \\
40 \mathrm{~m} \\
90 \mathrm{~m}\end{array}$ \\
\hline
\end{tabular}

crease mortality rates and injuries in reptiles, amphibians and carrion-feeding animals (Daigle 2010). Roads change the flows of water from the sub-soil drainage system (Andrews 1990) that may affect ground-dwelling arthropods. Roads also contribute to the creation of new artificial habitats which have impacts on adjacent areas at various distances (Bennett 1991; Reijnen et al. 1997). The larger the size of a road, the higher the expected impact on both dispersal patterns and landscape structure (Trombulak \& Frissell 2000; Holderegger \& Di Giulio 2010). In Hungary, the total road network length is $200,961 \mathrm{~km}$ and $211 \mathrm{~km}$ of road is located per $100 \mathrm{~km}^{2}$, and as such, represents the fourth densest road network among the member states of the European Union (www.ksh.hu). At present, the length of the Hungarian highway network is $1,481 \mathrm{~km}$ and is increasing yearly to satisfy human needs (Tari 2010). The verges of Hungarian highways represent more than 2,000 hectares of green surfaces (Kozár 2009).

In the present study, we focused on road effects on isopod diversity in highway verges. We investigated the variability of the ecological characteristics of isopod assemblages such as species richness, diversity, evenness and species composition, and the contribution of species differentiation (beta diversity) among habitat types. Firstly, we examined the differences in diversity between different types of adjacent areas to verges. Our hypothesis was that high isopod diversity occurs near urban habitats because of the spatial and temporal heterogeneity of the environment (McIntyre et al. 2001). We also studied differences between habitats at three distances from the edge of the roads to analyse the effect of the presence of a highway on isopods. Our hypothesis was that verges at medium distances from a road are more diverse than verges in close proximity and larger distance from roads, because the proximity of a road causes disturbance of habitats (Delgado et al. 2013b).

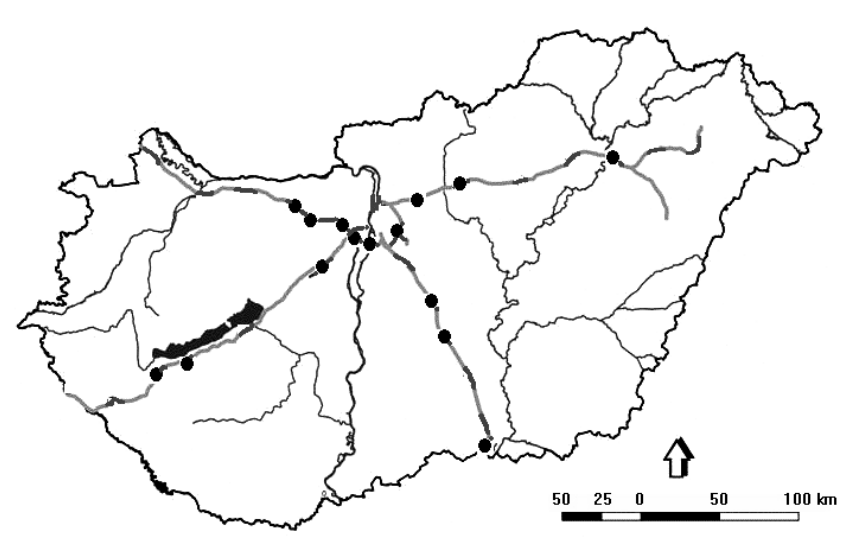

Fig. 1. Map of sampling sites in Hungary.

\section{Material and methods}

Sampling areas and methods

The study was carried out along five Hungarian highways (M0, M1, M3, M5, M7) between 2011-2013. The highway M0 is considered as a main road but is managed as a highway in Hungary. Highways M1 and M5 represent the Hungarian sections of the Brussels-Athens axis. The highways M7 and M3 are the Hungarian sections of the Rome-Kiyev axis. On the crossing point of the two highway axes, the M0 ring road located around the capital city of Hungary can be found. On the highway verges, we selected 15 sampling points that were located next to different types of adjacent areas: landscape type: $\mathrm{G}$ - grasslands, $\mathrm{F}$ - forest, $\mathrm{U}$ - urban habitats, $\mathrm{O}$ - orchards, A - arable land) (Figs 1, 2; Table 1). In order to analyse the effects of road edge proximity, we selected sampling sites at three distances from the edge of the roads (close: $20 \mathrm{~m}$, medium: $40 \mathrm{~m}$, and large: $90 \mathrm{~m}$ ) for all adjacent area types. Habitats in all verges were represented by uncharacteristically dry and semi-dry grasslands or closed sand steppes. Double-glass pitfall traps made of $3 \mathrm{dl}$ plastic cups filled with $65 \%$ aqueous solution of ethylene glycol were enclosed by fencing. Six traps were set at a distance of $4-5 \mathrm{~m}$ along a transect in each site. The traps were deployed three times (spring, summer, autumn) over 


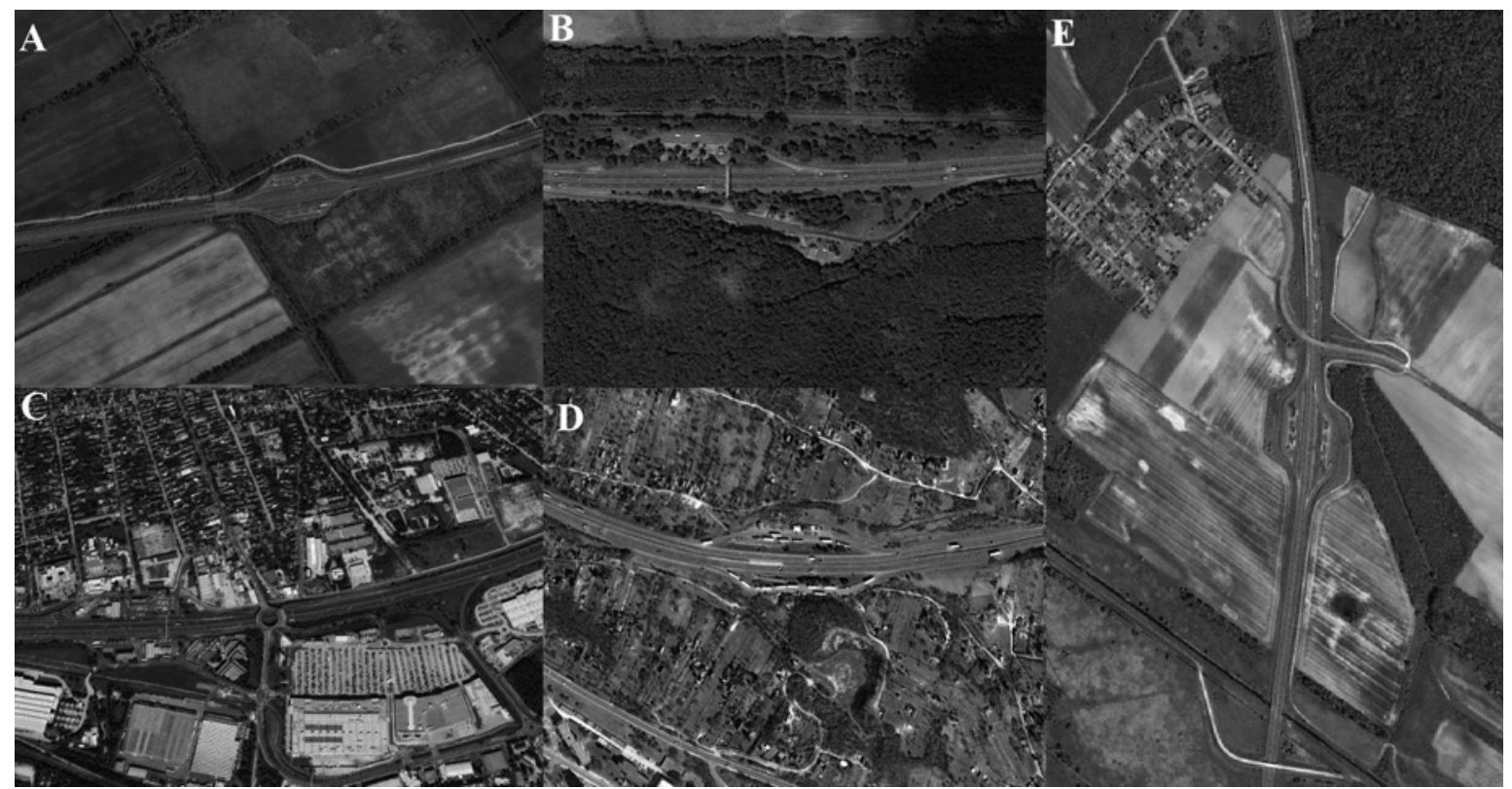

Fig. 2. Satellite images of sampling sites representing the five landscape types. A - grasslands (Táska), B - forests (Kisbag), C - urban areas (Budaörs), D - orchards (Turul), E - arable land (Szegerdő).

Table 2. The list of isopod species with their habitat preference, ecomorphotypes and origin.

\begin{tabular}{lcc}
\hline Species & Habitat preference & Ecomorphotypes \\
\hline Trichoniscus pusillus Brandt, 1833, & $\mathrm{G}$ & $\mathrm{C}$ \\
Porcellium collicola (Verhoeff, 1907) & $\mathrm{G}$ & $\mathrm{N}$ \\
Trachelipus nodulosus (C. Koch, 1838) & $\mathrm{G}$ & $\mathrm{S}$ \\
Trachelipus rathkii (Brandt, 1833) & $\mathrm{G}$ & $\mathrm{S}$ \\
Lepidoniscus minutus (C. Koch, 1838) & $\mathrm{NF}$ & $\mathrm{S}$ \\
Platyarthrus hoffmannseggii Brandt, 1833 & $\mathrm{G}$ & $\mathrm{S}$ \\
Protracheoniscus politus (C. Koch, 1841) & $\mathrm{NF}$ & $\mathrm{C}$ \\
Orthometopon planum (Budde-Lund, 1885) & $\mathrm{NF}$ & $\mathrm{N}$ \\
Porcellio scaber Latreille, 1804 & $\mathrm{G}$ & $\mathrm{N}$ \\
Porcellionides pruinosus (Brandt, 1833) & $\mathrm{G}$ & $\mathrm{N}$ \\
Armadillidium vulgare (Latreille, 1804) & $\mathrm{G}$ & $\mathrm{S}$ \\
Armadillidium nasatum Budde-Lund, 1885 & $\mathrm{K}$ \\
Armadillidium opacum (C. Koch, 1841) & $\mathrm{K}$ \\
\hline
\end{tabular}

Explanations: G - generalists, DR - disturbed-rare species, NF - natural-frequent species, NR - natural-rare species, C - creeper, $\mathrm{S}$ - surface active, $\mathrm{N}$ - native, I - introduced, $\mathrm{K}$ - cosmopolitan.

a three-week period each year. We used the keys of Hopkin (1991), Schmidt (1997), Berg \& Wijnhoven (1998) and Farkas \& Vilisics (2013) for identification of woodlice specimens. Species names were applied according to Schmalfuss (2003). The habitat preference (generalist, natural-frequent species, disturbed-rare species and natural-rare species) and ecomorphotypes (creeper and surface active) are based on classification by Hornung et al. $(2007,2009)$ and Vilisics \& Hornung (2010). The origin of species (native, cosmopolitan and introduced) is based on Vilisics \& Hornung (2008).

\section{Statistical analyses}

We used the PAST Paleontological Statistic suite for data analysis (Hammer et al. 2001). Besides number of individuals and species richness we computed Shannon-Wiener diversity and evenness (Pielou's index) in order to examine the diversity of isopods. The Shannon-Wiener index is more sensitive to the frequency of rare species (Nagendra 2002; Hill et al. 2003; Magurran 2003). The Pielou's evenness index shows the evenness of the distribution of species and is sensitive to changes in rare species (Hill et al. 2003; Magur- ran 2003). Margalef's richness index was used as a simple measure of species richness (Margalef 1958). We used the Wilson \& Shmida's Beta diversity index $(\beta \mathrm{T})$ in order to evaluate the value of species turnover between habitat types. The level of complementarity of habitats within the study habitats was characterized with Whittaker's $\beta$-diversity in$\operatorname{dex}(\beta \mathrm{W})$ (Magurran 2003). We used the Jaccard similarity index for pairwise comparison of similarities of areas based on species composition. This index calculates the similarity based on the absence and presence of the species (Schmera \& Erös 2008). Friedman's test was applied to compare the ecological indices using XLSTAT 14.0.7182.5000 version software (https://www.xlstat.com). Community separation was represented with Detrended Correspondence Analysis using XLSTAT 14.0.7182.5000 version software.

\section{Results}

A total of 13 isopod species comprising 22,430 individuals were collected at 15 sampling sites (Table 2). We 
Table 3. The differences between ecological parameters of verges in relation to adjacent areas and distance from the road by Friedmantest (Alpha $=0.05)$.

\begin{tabular}{lcc}
\hline & In relation to adjacent areas & In relation to distance from the road \\
\hline $\mathrm{Q}$ (Observed value) & 2.785 & 0.500 \\
$\mathrm{Q}$ (Critical value) & 9.488 & 5.991 \\
$\mathrm{DF}$ & 4 & 2 \\
$P$-value (Two-tailed) & 0.594 & 0.779 \\
\hline
\end{tabular}

Table 4. Number of isopod species (S), number of individuals (N), Shannon-Wiener diversity (H), Margalef's richness index (DMg) and the evenness $(\mathrm{E})$ in the verges in relation to types of adjacent areas.

\begin{tabular}{lccccc}
\hline & Grasslands & Forests & Urban areas & Orchards & Arable land \\
\hline $\mathrm{S}$ & 5 & 4 & 9 & 8 & 9 \\
$\mathrm{~N}$ & 3714 & 458 & 2233 & 1690 & 14335 \\
$\mathrm{H}$ & 0.2976 & 0.3137 & 0.8853 & 0.4144 & 0.0751 \\
$\mathrm{DMg}$ & 0.4866 & 0.4896 & 1.0370 & 0.9418 & 0.6269 \\
$\mathrm{E}$ & 0.2693 & 0.3421 & 0.2693 & 0.1892 & 0.1540 \\
\hline
\end{tabular}

Table 5. Number of isopod species (S), number of individuals (N), Shannon-Wiener diversity (H), Margalef's richness index (DMg) and the evenness $(\mathrm{E})$ in the verges located at different distances $(20 \mathrm{~m}, 40 \mathrm{~m}$ and $90 \mathrm{~m})$ from roads.

\begin{tabular}{lccc}
\hline & $20 \mathrm{~m}$ from roads & $40 \mathrm{~m}$ from roads & $90 \mathrm{~m}$ from roads \\
\hline $\mathrm{S}$ & 7 & 10 & 7 \\
$\mathrm{~N}$ & 3181 & 14776 & 4590 \\
$\mathrm{H}$ & 0.8838 & 0.1329 & 0.2743 \\
$\mathrm{DMg}$ & 0.7440 & 0.9374 & 0.7116 \\
$\mathrm{E}$ & 0.3457 & 0.1142 & 0.1879 \\
\hline
\end{tabular}
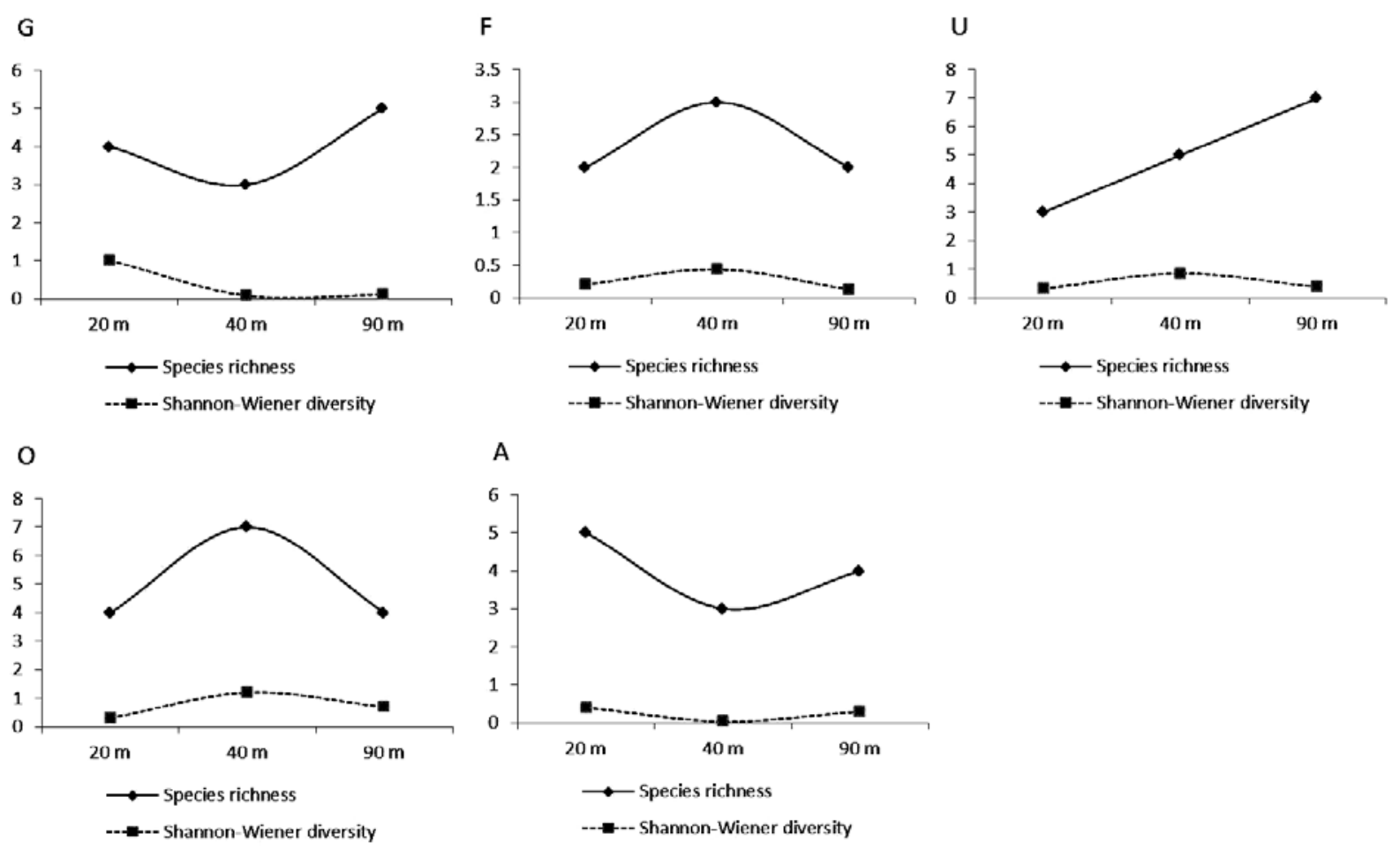

Fig. 3. Isopod species richness $(\mathrm{S})$ and the values of Shannon-Wiener index $(\mathrm{H})$ in verges $20 \mathrm{~m}, 40 \mathrm{~m}$ and $90 \mathrm{~m}$ from the edge of road relation to the different adjacent areas $(\mathrm{G}$ - grasslands, $\mathrm{F}$ - forest, $\mathrm{U}$ - urban areas, $\mathrm{O}$ - orchards, $\mathrm{A}$ - arable land).

found no significant differences between ecological parameters of isopod communities in relation to types of adjacent areas of verges (Table 3 ). The verges next to urban areas were characterized by the highest species 


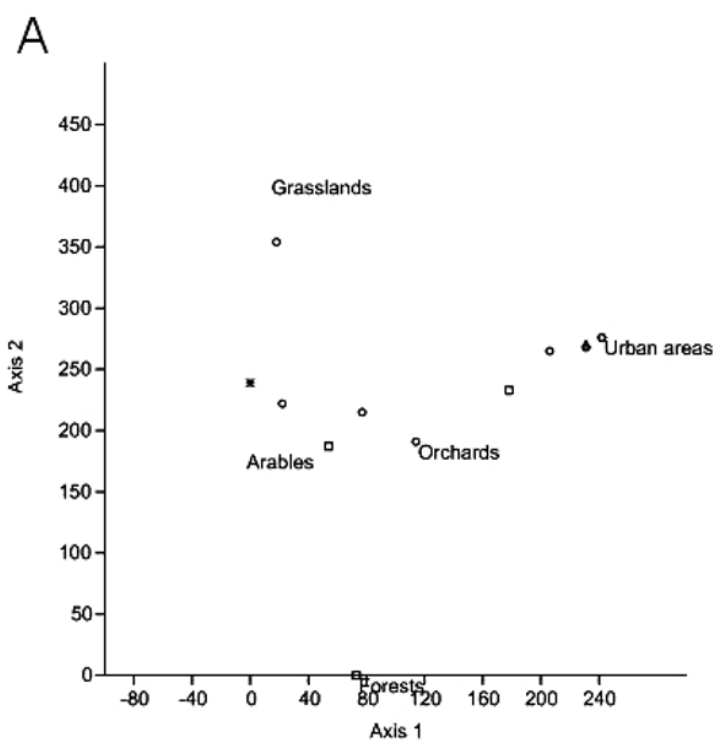

B

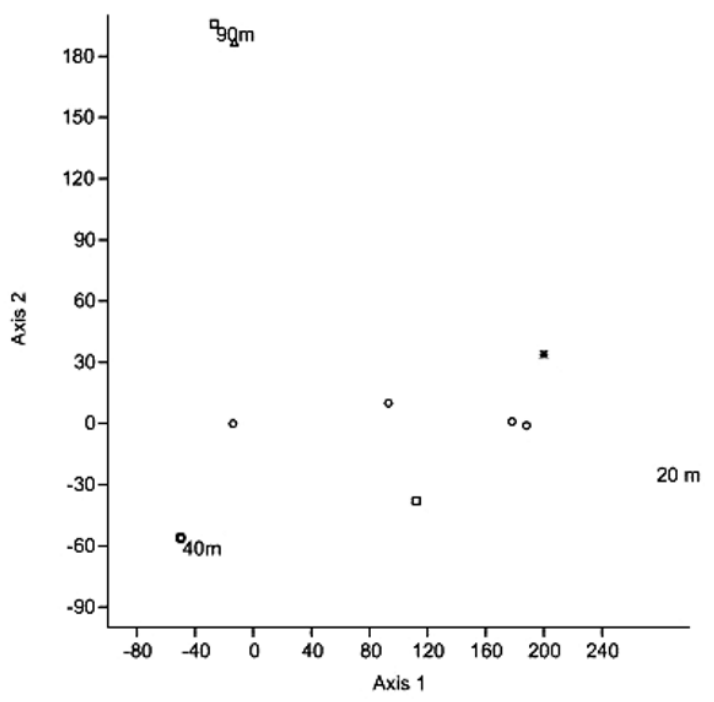

Fig. 4. The separation among the verges in relation to (A) adjacent area and (B) distance from the roads using Detrended Correspondence Analysis ( $\circ$ - generalists, $\square-$ natural-frequent species, $\boldsymbol{\Lambda}$ - disturbed-rare species $*$ - natural-rare species).

richness and diversity. The lowest species richness was found in verges next to forests, and the lowest diversity was observed next to arable land (Table 4). No significant differences were found between ecological parameters of isopod communities in relation to road edge proximity (Table 3 ). Species richness was the highest at a distance of $40 \mathrm{~m}$ from the road, but isopod diversity was the highest at $20 \mathrm{~m}$ distance from the highway (Table 5). Species diversity in different types of verges (based on adjacent areas) varied strongly in relation to road edge proximity. Diversity was higher $20 \mathrm{~m}$ from the road in case of verges located near grassland and arable land. In verges next to forests, orchards and urban areas diversity was higher at a $40 \mathrm{~m}$ distance from the road (Fig. 3).

The highest number of individuals was found in verges next to arable land and the lowest number oc-
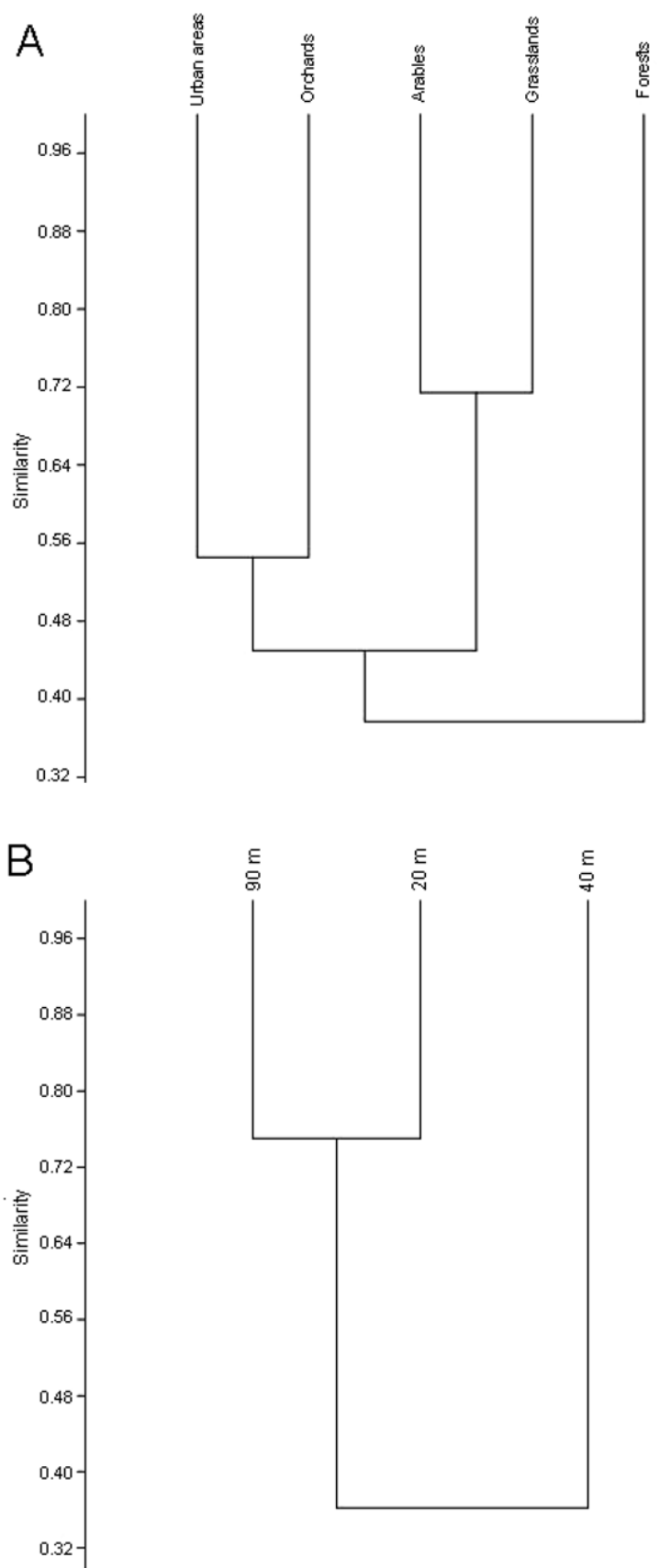

Fig. 5. Similarity of verges in relation to (A) adjacent area and (B) distance from the roads using Jaccard' similarity index.

curred in verges near forests. Differences were observed in verges according to the habitat-preferences of isopod species. In verges next to arable land all types of species (generalists, natural-frequent, disturbed-rare and natural-rare) were found. In verges next to seminatural habitats only two types of species were found, dominated by generalists. The ordination statistics demonstrated that species in verges are separated from each other based on adjacent areas. The disturbed areas (Table 1.) are situated closer to each other, whereas the semi-natural habitats are located far from the other areas and from each other (Fig. 4A). Regarding the road edge proximity, the occurrence of isopod species in verges varied. Only natural-rare species were present 
Table 6. Isopod species turnover between assemblages in verges in relation to different adjacent areas.

\begin{tabular}{lcccc}
\hline & & Wilson \& Shmida's Beta diversity index $(\beta \mathrm{T})$ \\
\cline { 2 - 4 } & Grasslands & Forests & Urban areas & Orchards \\
\hline Forests & 0.333 & 0 & 0.538 & 0.500 \\
Urban areas & 0.428 & 0.538 & 0.294 & 0 \\
Orchards & 0.384 & 0.500 & 0.294 & 0.375 \\
Arables & 0.1666 & 0.454 & 0.333 & 0.37 \\
\hline
\end{tabular}

Table 7. Isopod species turnover between different habitats in relation to the distance from a highway.

\begin{tabular}{lcc}
\hline & Wilson \& Shmida's Beta diversity index $(\beta \mathrm{T})$ \\
\cline { 2 - 3 } & $20 \mathrm{~m}$ from roads & $40 \mathrm{~m}$ from roads \\
\hline $40 \mathrm{~m}$ from roads & 0.411 & 0 \\
$90 \mathrm{~m}$ from roads & 0.142 & 0.529 \\
\hline
\end{tabular}

in verges at a distance of $20 \mathrm{~m}$ and $90 \mathrm{~m}$ from the road.

Regarding adjacent areas, we observed the highest species turnover between verges near forests and urban areas, and the lowest turnover between verges next to grasslands and arable land (Table 6). Regarding road edge proximity, the Wilson \& Shmida's Beta diversity index was highest between verges at distances of 40 $\mathrm{m}$ and $90 \mathrm{~m}$ from the roads (Table 7 ). According to Jaccard's similarity index, the highest similarity was observed between verges next to grasslands and arable land (0.71), followed by urban habitats and orchards (0.54), and forests and grasslands (0.50). There was a distinct difference among verges in relation to road edge proximity, showing the highest similarity between $20 \mathrm{~m}$ and $90 \mathrm{~m} \mathrm{(0.75)} \mathrm{(Fig.} \mathrm{5).} \mathrm{We} \mathrm{found} \mathrm{high} \mathrm{comple-}$ mentarity of species between these habitats which was demonstrated by high Whittaker's $\beta$ diversity (0.96).

\section{Discussion}

In this study, impacts of adjacent habitats of highway verges and their distance from highways on isopod communities were analysed. Few publications provide data about isopods of roadside verges, but several studies have shown the effects of roads on ground-dwelling arthropods (Noordijk 2006, 2008; Knapp et al. 2013) and litter invertebrates (Delgado et al. 2013a, b). We found significant differences between isopod communities in verges, depending on the characteristics of the adjacent areas. In contrast, Noordijk et al. (2008) did not observe differences between arthropod communities in roadside verges and the adjacent areas because of the similar vegetation in both areas.

Highway verges with adjacent urban areas can be characterised based on their complexity and heterogeneity. The urban fauna can be very diverse in many microhabitats (Riedel at al. 2009) due to the presence of exotic species (Jedryczkowsky 1981). Similar to Hornung et al. (2007) and Korsós et al. (2002), we observed the presence of a new invader exotic species, Armadillidium nasatum, in urban verges. In Hungary, this species was found to occur in greenhouses and big cities, but recently increasingly more outdoor occurrences were recorded, e.g. in the Transdanubian Hills (Vilisics \& Hornung 2010). The heterogeneous structure of synanthropic habitats provides suitable microhabitats and protection for the organisms from extreme weather conditions (Horváth 2012).

One of the key factors in the development of diversity is the structure of the landscape, in which the more complex configuration of a patch, the more habitat sources are available for organisms (Allik 2014). This may explain the highest isopod biodiversity next to urban areas. Thus, urban habitats are likely to be more important to the maintenance of biodiversity than other habitat types (Forman \& Alexander 1998; Alaruikka et al. 2002; Niemelä et al. 2002). Riedel et al. (2009) showed that urban soil provides substrate for native species typical of natural and semi-natural habitats in cities.

Highways can considerably change the local assemblages of ground-dwelling arthropods in Central Europe (Knapp et al. 2013). The potencial decrease in biodiversity is caused by the extinction of sensitive species, habitat damage (Henle et al. 2004) and the impacts of invasive species (Charles \& Dukes 2007). There is evidence that biodiversity of wildlife communities is significantly affected by roads (Bissonette 2002). Saunders et al. (2002) recorded that a road-effect is observed to a $300 \mathrm{~m}$ distance. Regarding road edge proximity, our data showed that isopod species diversity was significantly higher in verges than at more distant locations. This can be explained by the dominance of generalist species. These isopod species have a good colonizing ability and increased tolerance to habitat disturbances (Krauss et al. 2003). Delgado et al. (2013a) studied litter invertebrate species responses to road edges, and similar to our results, they showed that these species were found most frequently and in higher population densities at distances between 10 and $20 \mathrm{~m}$ from the roads. Delgado et al. (2013b) also observed that litter invertebrate species diversity was the highest at a dis- 
tance of $10 \mathrm{~m}$ from the edge of the road, which was explained by alteration of habitat structure due to roads, and the predictions of general niche theory. For all types of adjacent areas, we found the highest isopod diversity in verges situated $20 \mathrm{~m}$ or $40 \mathrm{~m}$ from the road. Thus, we can conclude that isopod diversity was less influenced by the type of adjacent areas than by the distance from the road.

Our results show that highway verges provide suitable environmental conditions mainly for generalist isopod species. Isopods are quite sensitive to low humidity, unstable temperatures and high insulation (Lee 2006). However, roadside verges function as green corridors which contribute to the spread of species, especially generalists with wide tolerance. Habitat loss and alteration, and the high abundance of generalist species, may be a limiting factor for specialist isopods along roads. Isopod diversity is influenced by road edge proximity and the landscape type. The proximity of roads and urban areas increases the species richness resulting in a high diversity of isopods along highways. The high species turnover between communities and the $96 \%$ of complementarity highlighted the heterogeneity of highway verges.

\section{Acknowledgements}

We thank to Kádár Ferenc for help in the sampling and the separation of the collected animals. We thank Illyés Eszter (deceased) and Molnár Csaba for the botany survey. The English was proofread by Andrew J. Hamer. Our project was funded by k83829 OTKA.

\section{References}

Alaruikka D.M., Kotze D.J., Matveinen K. \& Niemelä J. 2002. Carabid and spider assemblages along an urban to rural gradient in Southern Finland. J. Insect Conserv. 6: 195-206. DOI: $10.1023 / \mathrm{A}: 1024432830064$

Allik M. 2014. Exploring urban habitats. The case of Frihamnen. Sweden. Master's Thesis at Chalmers Architecture. Master Programme Design for Sustainable Development, $101 \mathrm{pp}$.

Andrews A. 1990. Fragmentation of habitat by roads and utility corridors: A review. Aust. Zool. 26 (3-4): 130-141. DOI: 10.7882/AZ.1990.005

Bennett A.F. 1991. Roads, roadsides and wildlife conservation: a review, pp. 99-118. In: Saunders D.A. \& Hobbs R.J. (eds), Nature Conservation 2: The Role of Corridors, Surrey Beatty, Chipping Norton, Australia, 442 pp. ISBN: 094-9-324-353

Berg M.P. \& Wijnhoven H. 1998. Landpissebedden. Een tabel voor de landpissebedden (Crustacea; Oniscidae) van Nederland en België. Wetenschappelijke Mededelingen KNNV 221: 1-80. ISBN: 9050111033

Bissonette J.A. 2002. Scaling roads and wildlife: the Cinderella principle. Z. Jagdwiss. 48 (Suppl. 1): 208-214. DOI: 10.1007/BF02192410

Bolger D.T., Suarez A.V., Crooks K.R., Morrison S.A. \& Case T.J. 2000. Arthropods in urban habitat fragments in southern California: area, age and edge effects. Ecol. Appl. 10 (4): 1230-1248. DOI: 10.1890/1051-0761(2000)010[1230:AIUHFI] 2.0. CO;2

Brisson J., de Blois S. \& Lavoie C. 2010. Roadside as invasion pathway for common reed (Phragmites australis). Invasive Plant Sci. Manag. 3 (4): 506-514. DOI: 10.1614/IPSM-09050.1
Charles H. \& Dukes J.S. 2007. Impacts of invasive species on ecosystem services, pp. 217-237. DOI: 10.1007/978-3-54036920-2_13. In: Nentwig W. (ed.), Biological Invasions. Ecological Studies (Analysis and Synthesis), Vol. 193, SpringerVerlag, Berlin, 446 pp. ISBN:978-3-540-77375-7

Daigle P. 2010. A summary of the environmental impacts of roads, management responses, and research gaps: A literature review. BC J. Ecosyst. Manage. 10 (3): 65-89.

Dallinger R., Berger B. \& Birkel S. 1992. Terrestrial isopods: useful bioindicators of urban metal pollution. Oecologia 89 (1): 32-41. DOI: 10.1007/BF00319012.

Delgado J.D., Arroyo N.L., Arévalo J.R. \& Fernández-Palacios J.M. 2013a. The responses of leaf litter invertebrates to environmental gradients along road edges in subtropical island forests. Pedobiology 56 (3): 137-146. DOI: 10.1016/j.pedobi. 2013.01.003

Delgado J.D., Arroyo N.L., Arévalo J.R. \& Fernández-Palacios J.M. 2013b. Road edge effects on litter invertebrate communities of subtropical forests. J. Nat. Hist. 47 (3-4): 203-236. DOI: $10.1080 / 00222933.2012 .743610$

Farkas S. \& Vilisics F. 2013. Magyarország szárazföldi ászkarák faunájának határozója (Isopoda: Oniscidea) [A Key to the Terrestrial Isopods of Hungary]. Nat. Somogy. 23: 89-124.

Forman R.T. \& Alexander L.E. 1998. Roads and their major ecological effects. Annu. Rev. Ecol. Syst. 29: 207-231. DOI: 10.1146/annurev.ecolsys.29.1.207

Forman R.T.T., Sperling D., Bisonete J.A. \& Clevenger A.P. (eds). 2002. Road Ecology: Science and Solutions. $2^{\text {nd }}$ ed. Island Press Washington, Covelo, London, 504 pp. ISBN: 1559639334, 9781559639330

Hammer O., Harper D.A.T. \& Ryan P.D. 2001. PAST: Paleontological Statistics software packege for education and data analysis. Palaeontol. Electron. 4 (1), 9 pp.

Hassall M., Turner J.G. \& Rands M.R.W. 1987. Effects of terrestrial isopods on the decomposition on woodland leaf litter. Oecologia 72 (4): 597-604. DOI: 10.1007/BF00378988

Hawbaker T.J., Radeloff V.C., Gonzalez-Abraham C.E., Hammer R.B. \& Clayton M.K. 2006. Changes in the road network, relationships with housing development, and the effects on landscape pattern in northern Wisconsin: 1937 to 1999. Ecol. Appl. 16 (3): 1222-1237. DOI: 10.1890/10510761(2006)016[1222:RDHGAL]2.0.CO;2

Henle K., Davies K.F., Kleyer M., Margules C. \& Settele J. 2004. Predictors of species sensitivity to fragmenttion. Biodivers. Conserv. 13: 207-215. DOI: 10.1023/B:BIOC.0000004319. $91643.9 \mathrm{e}$

Hill T.C.J., Walsh K.A., Harris J.A. \& Moffett B.F. 2003. Using ecological diversity measures with bacterial communities. FEMS Microbiol. Ecol. 43 (1): 1-11. DOI: 10.1111/j.15746941.2003.tb01040.x.

Holderegger R. \& Di Giulio M. 2010. The genetic effects of roads: a review of empirical evidence. Basic. Appl. Ecol. 11 (6): 522-531. DOI: 10.1016/j.baae.2010.06.006

Hopkin S.P. (ed.). 1991. A Key to the Woodlice of Britain and Ireland. AIDGAP, Field Studies Council Publication No. 204, 52 pp. ISBN-10: 1851532048, ISBN-13: 978-1851532049

Hornung E., Vilisics F. \& Sólymos P. 2009. Ászkarák együttesek (Crustacea, Isopoda, Oniscidea) felhasználhatósága élőhelyek minősítésében [The use of woodlice assemblages (Crustacea, Isopoda, Oniscidea) in the assessment of habitat naturalness]. Természetvédelmi Közlemények 15: 381-395.

Hornung E., Vilisics F. \& Szlávecz K. 2007. Hazai szárazföldi ászkarák fajok (Isopoda, Oniscidea) tipizálása két nagyváros, Budapest és Baltimore (ÉK Amerika) összehasonlításának példájával [Standardization of Hungarian terrestrial isopods comparing two big cities, Budapest and Baltimore (ÉK Amerika)]. Természetvédelmi Közlemények 13: 47-58.

Horvát R. 2012. Az urbanizáció hatása erdei talajlakó pókokra [Effect of urbanization on ground-dwelling spiders]. Természetvédelmi Közlemények 18: 224-233.

Jedryczkowsky W. 1981. Isopods (Isopoda) of Warsaw and Mazovia [Równonogi (Isopoda) Warszawy i Mazowsza]. Memorabilia Zool. 34: 79-86.

Knapp M., Saska P., Knappová J., Vonička P., Moravec P., Kurka A. \& Andel P. 2013. The habitat-specific effects of highway 
proximity on ground-dwelling arthropods: implications for biodiversity conservation. Biol. Conserv. 164: 22-29. DOI: 10.1016/j.biocon.2013.04.012

Korsós Z., Hornung E., Szlávecz K. \& Kontschán J. 2002. Isopoda and Diplopoda of urban habitats: new data to the fauna of Budapest. Annls. Hist.-Nat. Mus. Natn. Hung. 94: 193-208.

Kozár F. 2009. Pajzstetű (Hemiptera: Coocoidea) fajok és a klímaváltozás: Vizsgálatok magyarországi autópályákon [Scales species (Hemiptera, Coccoidea) and climate change studies in Hungarian highways]. Növényvédelem 45 (11): 577-588.

Krauss J., Steffan-Dewenter I. \& Tscharntke T. 2003. Local species immigration, extinction, and turnover of butterflies in relation to habitat area and habitat isolation. Oecologia 137 (4): 591-602. DOI: 10.1007/s00442-003-1353-x

Lee P. 2006. Atlas of the Millipedes (Diplopoda) of Britain and Ireland. Pensoft Publisher, Sofia-Moscow, 216 pp. ISBN-10: 9546422770, ISBN-13: 978-9546422774

Magurran A E. 2003. Measuring Biological Diversity. Blackwell Publishing, Oxford, 264 pp. ISBN: 978-0-632-05633-0

Margalef R. 1958. Temporal succession and spatial heterogeneity in phytoplankton, pp. 323-347. In: Margalef R. (ed.), Perspectives in Marine Biology, Buzzati-Traverso Univ. Calif. Press, Berkeley, 621 pp.

McIntyre N.E., Rango J., Fagan W.F. \& Faeth S.H. 2001. Ground arthropod community structure in a heterogenous urban environment. Landsc. Urban Plan. 52 (4): 257-274. DOI: 10.1016/S0169-2046(00)00122-5

Nagendra H. 2002. Opposite trends in response for the Shannon and Simpson indices of landscape diversity. Appl. Geogr. 22 (2): 175-186. DOI: 10.1016/S0143-6228(02)00002-4

Niemelä J., Kotze J.D., Venn S., Penev L., Stoyanov I., Spence J., Hartley D. \& Montes de Oca E. 2002. Carabid beetle assemblages (Coleoptera, Carabidae) across urban-rural gradients: an international comparison. Landsc. Ecol. 17 (5): 387-401. DOI: 10.1023/A:1021270121630

Noordijk J., Prins D., de Jonge M. \& Vermeulen R. 2006. Impact of a road on the movements of two ground beetle species (Coleoptera: Carabidae). Entomol. Fenn. 17: 276-283.

Noordijk J., Schaffers A.P., Heijerman T. \& Sykora K.V. 2011. Using movement and habitat corridors to improve the connectivity for heathland carabid beetles. J. Nat. Conserv. 19 (5): 276-284. DOI: 10.1016/j.jnc.2011.05.001

Noordijk J., Schaffers A.P. \& Sykora K.V. 2008. Diversity of ground beetles (Coleoptera: Carabidae) and spiders (Araneae) in roadside verges with grey hair-grass vegetation. Eur. J. Entomol. 105 (2): 257-265. DOI: 10.14411/eje.2008.036

Paoletti M.G. \& Hassall M. 1999. Woodlice (Isopoda, Oniscidea): their potential for assessing sustainability and use as bioindicators. Agr. Ecosyst. Environ. 74 (1-3): 157-165. DOI: $10.1016 /$ S0167-8809(99)00035-3

Purtauf T., Roschewitz I., Dauber J., Thies C., Tscharntke T. \& Wolters V. 2005. Landscape context of organic and conventional farms: influences on carabid beetle diversity. Agr. Ecosyst. Environ. 108 (2): 165-174. DOI: 10.1016/j.agee.2005.01.005

Reijnen R., Foppen R. \& Veenbaas G. 1997. Disturbance by traffic of breeding birds: evaluation of the effect and considerations in planning and mapping road corridors. Biodiv. Conserv. 6 (4): 567-581. DOI:10.1023/A:1018385312751

Riedel P., Navrátil M., Tuf I.H. \& Tufová J. 2009. Terrestrial isopods (Isopoda: Oniscidea) and millipedes (Diplopoda) of the City of Olomouc, pp. 125-132. In: Tajovský K., Schlaghamerský J. \& Pižl V. (eds), Contributions to Soil Zoology in Central Europe III. Proceedings of the $9^{\text {th }}$ Central European Workshop on Soil Zoology, České Budějovice, April 17-20, 2007, Institute of Soil Biology, Biology Centre, ASCR, v. v. i., České Budějovice, 191 pp. ISBN: 8086525139, 9788086525136
Ries L., Debinski D.M. \& Wieland M.L. 2001. Conservation value of roadside prairie restoration to butterfly communities. Conserv. Biol. 15 (2): 401-411. DOI: $10.1046 / \mathrm{j} .1523-$ 1739.2001.015002401.x

Saunders S.C, Mislivets M.R., Chen J. \& Cleland D.T. 2002. Effects of roads on landscape structure within nested ecological units of the Northern Great Lakes Region, USA. Biol. Conserv. 103 (2): 209-225. DOI: 10.1016/S0006-3207(01)00130-6

Schmalfuss H. 2003. World Catalog of Terrestrial Isopods (Isopoda: Oniscidea). Stuttgarter Beiträge zur Naturkunde, Serie A, Nr. 654, 341 pp.

Schmera D. \& Erős T. 2008. A mintavételi erőfeszítés hatása a mintareprezentativitásra [Effect of sampling effort ont he sample representativeness]. Acta Biol. Debrecina, Suppl. Oecol. Hung. 18: 209-213.

Schmidt C. 1997. Revision of the European species of the genus Trachelipus Budde-Lund, 1908 (Crustacea: Isopoda: Oniscidea). Zool. J. Linn. Soc. Lond. 121 (2): 129-244. DOI: 10.1111/j.1096-3642.1997.tb00337.x

Schmidt C. 2008. Phylogeny of the terrestrial Isopoda (Oniscidea): a review. Arthropod Syst. Phylogeny 66 (2): 191-226.

Smigel J.T. \& Gibbs A.G. 2008 Conglobation in the pill bug, Armadillidium vulgare, as a water conservation mechanism. J. Insect. Sci. 8: article 44. DOI: 10.1673/031.008.4401

Spencer J.O. \& Edney E.B. 1954. The absorption of water by woodlice. J. Exp. Biol. 31: 491-496.

Tari T. 2010. Autópálya vadátjárók kialakítása és használatuk értékelése. [Evaluation of formation and usage of highway wildlife crossing]. Doktori szigorlat/Doctoral thesis, NYME Erdőmérnöki Kar,/University of Sopron, Faculty of Forestry, Sopron, $26 \mathrm{pp}$.

Tikka P.M., Hogmander H. \& Koski P.S. 2001. Road and railway verges serve as dispersal corridors for grassland plants. Landsc. Ecol. 16 (7): 659-666. DOI: 10.1023/A:1013120529 382

Trombulak S.C. \& Frissell C.A. 2000. Review of ecological effects of roads on terrestrial and aquatic communities. Conserv. Biol. 14 (1): 18-30. DOI: 10.1046/j.1523-1739.2000.99084.x

Vilisics F. \& Hornung E. 2008. A budapesti szárazföldi ászkarákfauna (Isopoda: Oniscidea) kvalitatív osztályozása [Qualitative classification of the terrestrial isopod fauna (Isopoda: Oniscidea) of Budapest, Hungary. Állattani Közlemények 93 (2): 3-16.

Vilisics F. \& Hornung E. 2010. Újabb adatok Magyarország szárazföldi ászkarákfaunájához (Crustacea, Isopoda, Oniscidea) [New data to the terrestrial isopod (Crustacea, Isopoda, Oniscidea) fauna of Hungary. Állattani Közlemények 95 (1): 87-120.

Vona-Túri D., Szmatona-Túri T., Kádár F., Kiss B., Weiperth A. \& Gál B. 2016. Ground-dwelling arthropod (Araneae, Coleoptera: Carabidae, Isopoda: Oniscidea) assemblages on Hungarian main road verges. Acta Universitatis Sapientiae, Agriculture and Environment 8 (1): 98-113. DOI: 10.1515/ausae-2016-0009

Vona-Túri D., Szmatona-Túri T. \& Kiss B. 2013. Szárazföldi ászkarák együttesek (Crustacea: Isopoda: Oniscidea) a Magyarországi autópályák szegélyzónájába [Terrestrial isopods (Crustacea: Isopoda: Oniscidea) on Hungarian highway margins]. Természetvédelmi Közlemények 19: 106-116.

Vona-Túri D., Szmatona-Túri T. \& Kiss B. 2015. Autópályák ászkarák-közösségeinek (Crustacea: Isopoda: Oniscidea) ökológiai vizsgálata [Ecologic evaluation and diversity changes of terrestrial isopod assemblages (Crustacea: Isopoda: Oniscidea) on Hungarian highway margins]. Természetvédelmi Közlemények 21: 395-406.

Received July 10, 2017

Accepted October 26, 2017 